\title{
Effectiveness of some Insecticides against Larval Population of Two Major Defoliators of Soybean
}

\author{
Pragya Yadav ${ }^{1}$, V.K. Yadav ${ }^{2 *}$, S. Banerjee ${ }^{1}$ and M.P. Gupta ${ }^{2}$ \\ ${ }^{1}$ Department of Zoology, M. L. B. Govt. PG. College, Bhopal, India \\ ${ }^{2}$ Jawaharlal Nehru Krishi Vishwa Vidyalaya, India \\ *Corresponding author
}

\section{A B S T R A C T}

Keywords

Chemical control,

Semilooper, Tobacco

caterpillar,

Insecticides, Soybean

Article Info

Accepted:

10 January 2018

Available Online:

10 February 2018
The present investigation was carried out during kharif season 2010 and 2012 at farmers' field near College of Agriculture, Kundeshwar Road, Tikamgarh (M.P.). Nine insecticides were evaluated against semilooper and tobacco caterpillar on JS 93-05 variety of soybean in randomized complete block design with three replications. The result revealed that all the insecticides, under investigation, were found effective in reducing the population of semilooper and tobacco caterpillar over the unsprayed control. However, among the insecticides, indoxacarb (14.5 SC) was superior followed by lembda cyhalothrin (5 EC) in reducing the larval population of semilooper and tobacco caterpillar.

\section{Introduction}

Soybean is a unique crop with high nutritional value, providing 40 per cent protein and 20 per cent edible oil besides minerals and vitamins. It is playing an important role in augmenting both, the production of edible oil and protein simultaneously under the circumstances in which the shortage of these commodities being experienced by India.

Various names have been given to this important crop as Miracle bean, Golden bean, Cow of the field, Meat of the field, Gold from the soil, Pearl of the orient, Cinderella crop etc.
It is a major oil seed crop of world grown in an area of 113.01 million ha with production of 283.79 million tons and productivity of $2.51 \mathrm{t} / \mathrm{ha}$, India ranks fourth in world in respect of area and production (Anon., 2014). Major soybean growing states in India are Madhya Pradesh, Maharashtra, Rajasthan, Karnataka, Uttar Pradesh, Andhra Pradesh and Gujarat. In Madhya Pradesh, soybean occupies an area of 5.12 million ha with production of $5.85 \mathrm{mt}$ and productivity of $1142 \mathrm{~kg}$ per ha. In Indian scenario, Madhya Pradesh contributes about $53.88 \%$ and $59.06 \%$ in total area and production of soybean, respectively in the country and is known as "soya state" (Anon., 2010). 
The luxuriant crop growth, soft and succulent foliage attracts many insects and provides unlimited source of food, space and shelter. Soybean crop is reported to be attacked by about 350 species of insects in many parts of the world (Luckmann, 1971). Now a day infestation of defoliators is becoming the most important production constraint, posing threat to soybean cultivation in Madhya Pradesh. To minimize such serious damage on soybean, screening of effective insecticides for management of semilooper and tobacco caterpillar is needed. Hence, this study was conducted for evaluating the effectiveness of nine insecticides for the management of semilooper and tobacco caterpillar.

\section{Materials and Methods}

\section{Experimental site}

The experiment was carried out during Kharif season of 2010 and 2012 at farmers' field situated on Kundeshwar road, Tikamgarh (M.P.). The Tikamgarh District encompassing an area of $5048 \mathrm{Km}$ Co-ordinates of $24^{\circ} 26^{\prime}$; $25^{\circ} 40^{\prime}$ North latitudes and $78^{\circ} 26^{\prime}$ to $79^{\circ} 26^{\prime}$; East longitudes. It is nearly $1400 \mathrm{ft}$. from the sea level. It is situated in the northern part of M.P. The soil is heavy black clay and light in texture.

\section{Field preparation and Fertilizer application}

The field was ploughed and cross bakhared before sowing. Drainage channels were prepared at the time of sowing for drainage of excess rain water from the field. Fertilizer was applied at the time of sowing @ $20 \mathrm{~kg} \mathrm{~N}: 60 \mathrm{~kg}$ $\mathrm{P}_{2} \mathrm{O}_{5}: 20 \mathrm{~kg} \mathrm{~K} 2 \mathrm{O} /$ ha as basal dose.

\section{Seed rate and method of sowing}

The popular variety of soybean JS 93-05 was sown@80kg/ha in row by putting the seeds in furrows with row to row distance of $40 \mathrm{~cm}$ and $10 \mathrm{~cm}$ between plants. A randomized block design experiment with ten treatments was laid out to compare the efficacy of insecticides molecules against the incidence of semilooper, tobacco caterpillar in soybean. Plot size was kept $5 \times 2.80 \mathrm{~m}$ spacing between plot to plot was $70 \mathrm{~cm}$ and from one replication to other was kept $1 \mathrm{~m}$.

Nine insecticides were tested in the field against the semilooper and tobacco caterpillar. The treatments were Indoxacarb (14.5 SC) $500 \mathrm{ml}$, Rynaxypyr (20 SC) $100 \mathrm{ml}$, Diafenthiuron (50 WP) 500g, Profenophos (50 EC) $1250 \mathrm{ml}$, Lembda cyhalothrin (5EC) $300 \mathrm{ml}$, Endosulfan (35 EC) $1000 \mathrm{ml}$, Triazophos (40 EC) 800ml, Cypermethrin (25 EC) $600 \mathrm{ml}$, Chlorpyriphos (20 EC) 1500ml and Untreated control (Water spray).

The observation on larval population of defoliators was recorded per meter row length (mrl) leaving border rows.

Larval count was made by shaking the plants gently over a white cloth placed between the rows. Observations were recorded 1 day before treatment and 2 and 7 days after treatment (DAT).

\section{Results and Discussion}

It was observed that the soybean crop was attacked by semiloopers and tobacco caterpillar during crop growing period. The pest population in different treatments was averaged for both the years under study and computed for description.

\section{Comparative efficacy of insecticides against the incidence of defoliators of soybean}

Four commonly used insecticides and five new molecules were screened against major insects of soybean under field condition during 2010 and 2012. The larval population 
in different observations was averaged for both the years under study and data were used for description.

Observations on the larval population of semilooper and tobacco caterpillar were recorded 1 day before and 2 and 7 days after treatment in per meter row length $(\mathrm{mrl})$.

\section{One day before the application of} insecticides

The data presented in Table 1 indicated that during 2010 larval population of semilooper ranged from 2.84 to 3.26 larvae/mrl, whereas it ranged from 5.25 to 6.59 larvae/mrl during 2012.

Observations were recorded 1 day before the application of insecticides revealed that all the treatments had more or less similar number of semiloopers and ranged from 4.12 to 4.86 larvae/ mrl which were uniformly distributed in all the plots. Statistically a non-significant variation was recorded in the semiloopers population at this stage.

Two days after the application of insecticides

The data presented in Table 2 indicated that during 2010 larval population of semilooper ranged from 0.67 to 1.56 larvae/mrl as compared to 3.90 larvae/mrl in control whereas it ranged from 3.06 to 4.69 larvae/mrl during 2012.

After 2 days of insecticidal application, all the treatments were significantly superior over the control. Indoxacarb, lembda cyhalothrin, triazophos, profenophos, cypermethrin, were at par with each other and were more effective than rynaxypyr, endosulfan, diafenthiuron and chlorpyriphos (Table 2) in reducing the larval population during both the years and also in pooled mean larval population.
Seven days after the application of insecticides

The data presented in Table 2 indicated that during 2010 larval population of semilooper ranged from 0.97 to 1.67 larvae $/ \mathrm{mrl}$ as compared to 3.60 larvae/mrl in control whereas it ranged from 3.53 to 4.86 larvae/mrl during 2012. After 7 days of insecticidal spray, all insecticidal treatments were found effective and significantly superior over untreated control in reducing larval population. The population of semiloopers is presented in the Table 2. All the treatments recorded significantly less larval population (2.25 to 3.20 larvae/mrl) as compared to untreated control. Among the insecticides, indoxacarb was superior followed by lembda cyhalothrin, triazophos, profenophos, cypermethrin, rynaxypyr, endosulfan, diafenthiuron and Chlorpyriphos. Significantly lowest larval population was recorded in indoxacarb (2.25 larvae/mrl) and it was at par with all the treatments except endosulfan, diafenthiuron, chlorpyriphos. However, all the insecticidal treatments were significantly superior over control (6.20 larvae/mrl).

Rajput et al., (1996) reported quinalphos $(0.05 \%)$ and cypermethrin $(0.01 \%)$ as highly effective against the green semilooper. Singh (1995) reported triazophos $(0.04 \%)$, acephate $(0.07 \%)$, Chlorpyriphos $(0.05 \%)$, methomyl $(0.04 \%)$, ethion $(0.1 \%)$, endosulfan $(0.07 \%)$ and quinalphos $(0.05 \%)$ were highly toxic against the grey semilooper on soybean up to 15 days after treatment. Singh and Singh (1988), found that monocrotophos $(0.036 \%)$, triazophos $(0.04 \%)$ and fenvalerate $(0.01 \%)$ to be highly effective against the grey semilooper. Singh and Singh (1990) reported quinalphos $(1.5 \%$ dust $)$ against Diacrisia orichalcea and cypermethrin (0.01\%), deltamethrin $(0.01 \%)$ and quinalphos $(0.05 \%)$ against Chrysodeixis acuta respectively to be the most effective. 
Table.1 Population of semiloopers before insecticidal application

\begin{tabular}{|l|}
\hline Treatments \\
\hline Indoxacarb (14.5 SC) \\
\hline Rynaxypyr (20 SC) \\
\hline Diafenthiuron (50 WP) \\
\hline Profenophos (50 EC) \\
\hline Lembda cyhalothrin (5 EC) \\
\hline Endosulfan (35 EC) \\
\hline Triazophos (40 EC) \\
\hline Cypermethrin (25 EC) \\
\hline Chlorpyriphos (20 EC) \\
\hline Untreated control \\
\hline SEm \\
\hline
\end{tabular}

CD at $5 \%$

\begin{tabular}{|l|c|c|c|}
\hline \multirow{2}{*}{ Dose/ha } & \multicolumn{3}{|c|}{ 1 day before treatment } \\
& Mean larval population (larvae/mrl) \\
\hline $500 \mathrm{ml}$ & 3.13 & 6.59 & 4.86 \\
\hline $100 \mathrm{ml}$ & 3.25 & 5.39 & 4.32 \\
\hline $500 \mathrm{~g}$ & 3.11 & 5.58 & 4.35 \\
\hline $1250 \mathrm{ml}$ & 2.85 & 5.93 & 4.39 \\
\hline $300 \mathrm{ml}$ & 3.26 & 5.25 & 4.26 \\
\hline $1000 \mathrm{ml}$ & 2.87 & 5.37 & 4.12 \\
\hline $800 \mathrm{ml}$ & 2.84 & 6.48 & 4.66 \\
\hline $600 \mathrm{ml}$ & 3.04 & 6.42 & 4.73 \\
\hline $1500 \mathrm{ml}$ & 3.21 & 5.56 & 4.39 \\
\hline & 3.13 & 6.04 & 4.58 \\
\hline & 0.38 & 0.45 & 0.31 \\
\hline
\end{tabular}

Table. 2 Efficacy of different insecticides on the larval population of semiloopers after 2 and 7 days of treatment

\begin{tabular}{|c|c|c|c|c|c|c|c|}
\hline \multirow[t]{2}{*}{ Treatments } & \multirow[t]{2}{*}{ Dose/ha } & \multicolumn{3}{|c|}{$\begin{array}{l}\text { Two days after treatment } \\
\text { Mean larval population } \\
\text { (larvae/mrl) }\end{array}$} & \multicolumn{3}{|c|}{$\begin{array}{l}\text { Seven days after treatment } \\
\text { Mean larval population } \\
\text { (larvae/mrl) }\end{array}$} \\
\hline & & 2010 & 2012 & Pooled & 2010 & 2012 & Pooled \\
\hline Indoxacarb (14.5 SC) & $500 \mathrm{ml}$ & 0.67 & 3.06 & 1.87 & 0.97 & 3.53 & 2.25 \\
\hline Rynaxypyr (20 SC) & $100 \mathrm{ml}$ & 1.21 & 4.19 & 2.70 & 1.34 & 4.46 & 2.90 \\
\hline $\begin{array}{l}\text { Diafenthiuron } \\
\text { WP) }\end{array}$ & $500 \mathrm{~g}$ & 1.40 & 4.69 & 3.05 & 1.46 & 4.86 & 3.16 \\
\hline Profenophos (50 EC) & $1250 \mathrm{ml}$ & 1.11 & 3.73 & 2.42 & 1.27 & 3.83 & 2.55 \\
\hline $\begin{array}{l}\text { Lembda cyhalothrin } \\
\text { (5 EC) }\end{array}$ & $300 \mathrm{ml}$ & 0.96 & 3.49 & 2.22 & 1.14 & 3.57 & 2.36 \\
\hline Endosulfan (35 EC) & $1000 \mathrm{ml}$ & 1.24 & 4.37 & 2.81 & 1.40 & 4.45 & 2.93 \\
\hline Triazophos (40 EC) & $800 \mathrm{ml}$ & 1.11 & 3.57 & 2.34 & 1.22 & 3.67 & 2.45 \\
\hline $\begin{array}{l}\text { Cypermethrin } \\
\text { EC) }\end{array}$ & $600 \mathrm{ml}$ & 1.12 & 3.76 & 2.44 & 1.31 & 3.91 & 2.61 \\
\hline $\begin{array}{l}\text { Chlorpyriphos } \\
\text { EC) }\end{array}$ & $1500 \mathrm{ml}$ & 1.56 & 4.53 & 3.05 & 1.67 & 4.71 & 3.20 \\
\hline Untreated control & & 3.90 & 8.42 & 6.16 & 3.60 & 8.57 & 6.20 \\
\hline SEm+ & & 0.15 & 0.30 & 0.20 & 0.17 & 0.35 & 0.23 \\
\hline CD at $5 \%$ & & 0.45 & 0.89 & 0.59 & 0.49 & 1.03 & 0.67 \\
\hline
\end{tabular}


Table.3 Population of tobacco caterpillar before insecticidal application

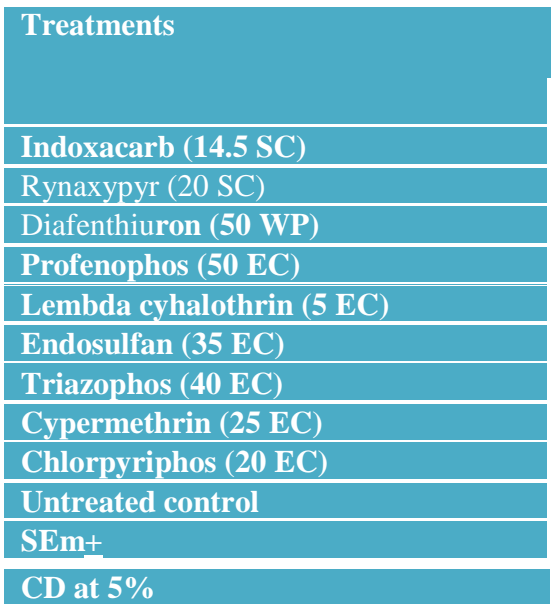

\begin{tabular}{|l|c|c|c|}
\hline \multirow{2}{*}{ Dose/ha } & \multicolumn{3}{|c|}{$\begin{array}{c}\text { 1 day before treatment } \\
\text { Mean larval population (larvae/mrl) }\end{array}$} \\
\hline & $\mathbf{2 0 1 0}$ & 2012 & Pooled \\
\hline $500 \mathrm{ml}$ & 2.43 & 3.30 & 2.87 \\
\hline $100 \mathrm{ml}$ & 2.57 & 3.97 & 3.27 \\
\hline $500 \mathrm{~g}$ & 2.18 & 2.98 & 2.58 \\
\hline $1250 \mathrm{ml}$ & 2.40 & 3.83 & 2.85 \\
\hline $300 \mathrm{ml}$ & 2.94 & 3.76 & 3.07 \\
\hline $1000 \mathrm{ml}$ & 2.22 & 3.47 & 2.74 \\
\hline $800 \mathrm{ml}$ & 2.03 & 3.63 & 2.63 \\
\hline $600 \mathrm{ml}$ & 2.83 & 3.31 & 3.07 \\
\hline $1500 \mathrm{ml}$ & 2.86 & 3.33 & 3.10 \\
\hline & 2.72 & 3.32 & 3.02 \\
\hline & 0.44 & 0.78 & 0.52 \\
\hline
\end{tabular}

Table.4 Efficacy of different insecticides on the larval population of tobacco caterpillar after 2 and 7 days of treatment

\begin{tabular}{|l|}
\hline Treatments \\
\hline Indoxacarb (14.5 SC) \\
\hline Rynaxypyr (20 SC) \\
\hline Diafenthiuron (50 WP) \\
\hline Profenophos (50 EC) \\
\hline Lembda cyhalothrin (5 EC) \\
\hline Endosulfan (35 EC) \\
\hline Triazophos (40 EC) \\
\hline Cypermethrin (25 EC) \\
\hline Chlorpyriphos (20 EC) \\
\hline Untreated control \\
\hline SEm + \\
\hline CD at 5\%
\end{tabular}

\begin{tabular}{|l|l|l|l|}
\hline \multirow{2}{*}{ Dose/ha } & \multicolumn{3}{|l|}{$\begin{array}{l}\text { Two days after treatment } \\
\text { Mean larval population (larvae/mrl) }\end{array}$} \\
\hline & $\mathbf{2 0 1 0}$ & 2012 & Pooled \\
\hline $500 \mathrm{ml}$ & 0.92 & 1.14 & 1.03 \\
\hline $100 \mathrm{ml}$ & 1.52 & 1.72 & 1.62 \\
\hline $500 \mathrm{~g}$ & 1.41 & 1.94 & 1.67 \\
\hline $1250 \mathrm{ml}$ & 1.30 & 1.91 & 1.61 \\
\hline $300 \mathrm{ml}$ & 1.14 & 1.90 & 1.52 \\
\hline $1000 \mathrm{ml}$ & 1.90 & 2.18 & 2.04 \\
\hline $800 \mathrm{ml}$ & 1.22 & 2.09 & 1.66 \\
\hline $600 \mathrm{ml}$ & 2.37 & 2.59 & 2.48 \\
\hline $1500 \mathrm{ml}$ & 2.27 & 2.15 & 2.21 \\
\hline & 3.65 & 3.18 & 3.42 \\
\hline & 0.15 & 0.29 & 0.17 \\
\hline & 0.44 & 0.85 & 0.51 \\
\hline
\end{tabular}

\begin{tabular}{|c|c|c|}
\hline \\
\hline 2010 & 2012 & $\begin{array}{l}\text { Seven days after treatment } \\
\text { Mean larval population (larvae/mrl) }\end{array}$ \\
\hline 1.03 & 1.41 & 1.22 \\
\hline 1.66 & 1.96 & 1.81 \\
\hline 1.52 & 1.89 & 1.71 \\
\hline 1.33 & 1.75 & 1.54 \\
\hline 1.26 & 1.74 & 1.50 \\
\hline 2.16 & 2.34 & 2.26 \\
\hline 1.44 & 1.91 & 1.67 \\
\hline 2.55 & 2.84 & 2.70 \\
\hline 2.53 & 2.20 & 2.37 \\
\hline 3.82 & 4.22 & 4.02 \\
\hline 0.19 & 0.21 & 0.12 \\
\hline 0.58 & 0.63 & 0.34 \\
\hline
\end{tabular}

Table.5 Effect of insecticidal treatments on yield of soybean

\begin{tabular}{|l|}
\hline Treatments \\
\hline Indoxacarb (14.5 SC) \\
\hline Rynaxypyr (20 SC) \\
\hline Diafenthiuron (50 WP) \\
\hline Profenophos (50 EC) \\
\hline Lembda cyhalothrin(5 EC) \\
\hline Endosulfan (35 EC) \\
\hline Triazophos (40 EC) \\
\hline Cypermethrin (25 EC) \\
\hline Chlorpyriphos (20 EC) \\
\hline Untreated control \\
\hline SEm \pm \\
\hline
\end{tabular}

\begin{tabular}{|l|c|c|}
\hline \multirow{2}{*}{ Dose/ha } & \multicolumn{2}{|c|}{ Yield (Kg/ha) } \\
\hline $500 \mathrm{ml}$ & $\mathbf{2 0 1 0}$ & $\mathbf{2 0 1 2}$ \\
\hline $100 \mathrm{ml}$ & 1523.60 & 1434.13 \\
\hline $500 \mathrm{~g}$ & 1229.67 & 1148.33 \\
\hline $1250 \mathrm{ml}$ & 1234.667 & 1141.67 \\
\hline $300 \mathrm{ml}$ & 1290.74 & 1175.87 \\
\hline $1000 \mathrm{ml}$ & 1119.45 & 1260.53 \\
\hline $800 \mathrm{ml}$ & 1257.85 & 1087.3 \\
\hline $600 \mathrm{ml}$ & 1127.41 & 1213.2 \\
\hline $1500 \mathrm{ml}$ & 1100.38 & 1123.33 \\
\hline & 957.10 & 1090.98 \\
\hline & 115.63 & 939.3 \\
\hline & $\mathbf{N S}$ & 74.17 \\
\hline
\end{tabular}

\begin{tabular}{|c|}
\hline Pooled \\
\hline 1478.87 \\
\hline 1189.00 \\
\hline 1166.43 \\
\hline 1205.27 \\
\hline 1275.64 \\
\hline 1103.38 \\
\hline 1235.53 \\
\hline 1125.38 \\
\hline 1095.69 \\
\hline 948.20 \\
\hline 84.14 \\
\hline 248.23 \\
\hline
\end{tabular}


The insecticides tested and found effective in reducing the insect population and increasing yield, some of these insecticides were also previously tested and found superior by these workers.

Hence the findings are in continuation and accordance with these workers.

\section{Effect of insecticides on larval population of tobacco caterpillar}

One day before the application of insecticides

The data presented in Table 3 indicated that during 2010 larval population of tobacco caterpillar ranged from 2.18 to 2.94 larvae/mrl, whereas, it ranged from 2.98 to 3.97 larvae/mrl during 2012.

The pre-treatment population of tobacco caterpillar was uniformly distributed in all the plots, and ranged between 2.58 to 3.27 larvae/meter row length (mrl), and difference was statistically non-significant (Table 3 ).

Two days after the application of insecticides

The data presented in Table 4 indicated that during 2010 larval population of tobacco caterpillar ranged from 0.92 to 2.37 larvae/mrl as compared to 3.65 larvae/mrl in control whereas it ranged from 1.14 to 2.59 larvae/mrl during 2012.

After 2 days of insecticidal treatment, all the treatments were significantly superior over the control. Indoxacarb and lembda cyhalothrin were the most effective treatments followed by profenophos, rynaxypyr, triazophos, diafenthiuron, endosulfan, chlorpyriphos and cypermethrin during both years and in pooled mean population (Table 4).
Seven days after the application of insecticides

The data presented in Table 4 indicated that during 2010 larval population of tobacco caterpillar ranged from 1.03 to 2.55 larva/mrl as compared to 3.82 larva/mrl in control whereas it ranged from 1.41 to 2.84 larva/mrl during 2012.

A reduction in the pest population was observed after 7 days of the spray in the various treatments. The minimum number of tobacco caterpillar was recorded in indoxacarb (1.22 larvae/meter), which was effective and significantly superior over all the other treatments except lembda cyhalothrin and profenophos.

The least effective insecticide on the tobacco caterpillar was found to be cypermethrin with 2.70 larvae/meter. The maximum number of tobacco caterpillar was recorded under the untreated control (4.02 larvae/ meter). However, all insecticides were significantly superior over control (TabIe 4).

\section{Effect of various treatments on yield of soybean}

The data presented in Table 5 indicated that during 2010 soybean yield ranged from 1100.38 to $1523.60 \mathrm{~kg} / \mathrm{ha}$ as compared to $957.10 \mathrm{~kg} / \mathrm{ha}$ in control, whereas, it ranged 1087.3 to $1434.13 \mathrm{~kg} / \mathrm{ha}$ during 2012. The effect of different treatments on yield is presented in Table 5. The maximum yield was recorded in indoxacarb (1478.87 kg/ha), which was found to be significantly superior over other treatments and control. Although it was found that most of the insecticidal treatments were superior over control but lembda cyhalothrin (1275.64 kg/ha) and triazophos $(1235.53 \mathrm{~kg} / \mathrm{ha})$, were at par with the indoxacarb. The minimum yield of 948.20 $\mathrm{kg} / \mathrm{ha}$ was recorded in control $(948.2 \mathrm{~kg} / \mathrm{ha})$. 
Yadav et al., (2001) found chlorpyriphos 50 $\mathrm{EC}+$ cypermethrin $5 \mathrm{EC}$ gave maximum yield followed by quinalphos $20 \mathrm{AF}$ and lambda cyhalothrin 5 EC. Singh et al., (1998) also found fanvalerate and quinalphos to be more effective for getting higher produce. Higher grain yield of soybean recorded as a result of effective chemical control of insectpests with endosulfan (Venkateshan and Kundu, 1994). Increase in yield by the application of insecticides over control has also been reported by various workers. Therefore the results in present study are in support and confirmation with these workers.

\section{References}

Anonymous, 2010. Agricultural Statistics At a Glance 2010, Ministry of Agriculture, Govt of India, Pp. 510.

Anonymous, 2014. Annual report, 2013-14, Directors Report, All India Coordinated Research Project on soybean, Indore M. P., pp. 341.

Luckmann, W.H. 1971. The insect pests of soybean. World farm. 13(5): 18-19 \& 22.

Rajput, P. S., Singh, O. P., Saxena, A. and Das, S. B. 1996. Studies on efficacy and economics of some insecticides as emulsion against major pests of soybean. Bhartiya Krishi Anusandhan Patrika. 11(3): 173-178.
Singh, K.J., Singh, O.P. and Choudhary, A.K. 1998. Chemical control of major insect pests of soybean in Madhya Pradesh. $J$. Insect Sci. 11(2): 145-148.

Singh, O. P. and Singh, K. J. 1987. New record of Amyna octo Guenee (Lepidoptera: Noctuidae) as pest of soybean in Madhya Pradesh, India. Indian J. Plant Prot. 15: 95-96.

Singh, O. P. and Singh, K. J. 1990. Seasonal incidence and damage of Melanagromyza sojae (Zehnt.) on soybean. Indian J. Plant Prot. 18: 271275.

Singh, O.P. 1995. Summary of results of entomological trials conducted during kharif 1995 pp. 222-223 in project Coordinators report and summary tables of experiment, AICRP on Soybean (Indore).

Venkatesan, T. and Kundu, G. G. 1994. Yield infestation relationship and determination of economic injury level of stem fly, Melanagromyza sojae (Zehnter) infesting soybean. J. Ent. Res. 18(3): 265-270.

Yadav, M. K., Matkar, S. M., Sharma, A. N., Billore, M, Kapoor, K. N. and Patidar, G. L. 2001. Efficacy and economics of some new insecticides against defoliators and stem borers of soybean [Glycine $\max$ (L.) Merrill]. Crop Research Hisar. 21(1): 88-92.

\section{How to cite this article:}

Pragya Yadav, V.K. Yadav, S. Banerjee and Gupta, M.P. 2018. Effectiveness of some Insecticides against Larval Population of Two Major Defoliators of Soybean. Int.J.Curr.Microbiol.App.Sci. 7(02): 1066-1072. doi: https://doi.org/10.20546/ijcmas.2018.702.132 